\title{
Potato virus $Y$ Transmission Efficiency from Potato Infected with Single or Multiple Virus Strains
}

\author{
Shaonpius Mondal, Yu-Hsuan Lin, Juliet E. Carroll, Erik J. Wenninger, Nilsa A. Bosque-Pérez, Jonathan L. Whitworth, \\ Pamela Hutchinson, Sanford Eigenbrode, and Stewart M. Gray
}

First and seventh authors: Department of Plant, Soil, and Entomological Sciences, University of Idaho, Aberdeen Research \& Extension Center, University of Idaho, Aberdeen, ID 83210; second and ninth authors: Section of Plant Pathology and Plant-Microbe Biology, School of Integrative Plant Science, Cornell University, Ithaca, NY 14853-5904; third author: New York State IPM Program and Section of Plant Pathology and Plant-Microbe Biology Cornell University, 630 W. North St., Geneva, NY 14456; fourth author: Department of Plant, Soil, and Entomological Sciences, University of Idaho, Kimberly Research \& Extension Center, University of Idaho, Kimberly, ID 83341-5082; fifth and eighth authors: Department of Plant, Soil, and Entomological Sciences, University of Idaho, 875 Perimeter Drive, Moscow, ID 838442339; sixth author: United States Department of Agriculture-Agricultural Research Service (USDA-ARS), Small Grains and Potato Germplasm Research, Aberdeen, ID 83210; and ninth author: USDA-ARS, Emerging Pests and Pathogen Research Unit, Robert W. Holley Center for Agriculture and Heath, Cornell University, Ithaca, NY 14853-5904.

Current address of S. Mondal: Section of Plant Pathology and Plant-Microbe Biology, School of Integrative Plant Science, Cornell University, Ithaca, NY 14853-5904.

Accepted for publication 3 December 2016.

\begin{abstract}
There has been a recent shift in the prevalence of Potato virus $Y$ (PVY) strains affecting potato with the ordinary strain $\mathrm{PVYO}$ declining and the recombinant strains PVYNTN and PVY ${ }^{\mathrm{N}: \mathrm{O}}$ emerging in the United States. Multiple PVY strains are commonly found in potato fields and even in individual plants. Factors contributing to the emergence of the recombinant strains are not well defined but differential aphid transmission of strains from single and mixed infections may play a role. We found that the transmission efficiencies by Myzus persicae, the green peach aphid, of PVYNTN, PVYN:O, and PVYO varied depending on the potato cultivar serving as the virus source. Overall transmission efficiency

was highest from sources infected with three virus strains, whereas transmission from sources infected with one or two virus strains was not significantly different. Two strains were concomitantly transmitted by individual aphids from many of the mixed-source combinations, especially if $\mathrm{PVY}^{\mathrm{O}}$ was present. Triple-strain infections were not transmitted by any single aphid. PVYO was transmitted most efficiently from mixed-strain infection sources. The data do not support the hypothesis that differential transmission of PVY strains by M. persicae is a major contributing factor in the emergence of recombinant PVY strains in the U.S. potato crop.
\end{abstract}

Potato (Solanum tuberosum L.) is an economically important, highvalue crop in the United States and is the major noncereal staple food crop worldwide (FAO 2008). Potato virus Y (PVY), the type member of the family Potyviridae, is distributed in potato-growing areas throughout the world (Gray et al. 2010; Karasev and Gray 2013; Kerlan and Moury 2008) and can severely constrain potato production by affecting yield and tuber quality (Gray et al. 2010; Ragsdale et al. 2001). PVY is the major reason for the rejection of seed lots by U.S. and other national seed certification programs (Frost et al. 2013). An emerging concern regarding PVY is the increasing prevalence of recombinant strains relative to the ordinary strain, $\mathrm{PVYO}$ (Gray et al. 2010; Karasev and Gray 2013). Unlike PVYO, which generally causes readily observable foliar mosaic, necrosis, and leaf drop symptoms, the recombinant strains (PVYNTN, PVYNA-NTN, PVYN:O, and $\mathrm{PVY} \mathrm{Y}^{\mathrm{N}-\mathrm{Wi}}$ ) often induce mild or transient foliar mosaic symptoms. Moreover, the recombinant strains are more likely to cause potato tuber necrotic ringspot disease of varying severity in many important North American potato cultivars, including 'Yukon Gold', 'Red Norland', 'Yukon Gem', 'Highland Russet', 'Alturas', and 'Ranger Russet' (McDonald and Singh 1996; Nolte et al. 2004; van den Heuvel et al. 1994; Whitworth et al. 2006).

Recombinant PVY strains were first reported in North America from Canada in 1991 (Singh 1992) and the United States in 2002

Corresponding author: S. M. Gray; E-mail address: smg3@ cornell.edu

(C) 2017 The American Phytopathological Society
(Crosslin et al. 2002). Subsequent reports and surveys have shown a rapid shift in geographic distribution and relative incidence of PVY strains in potato in the United States and Canada (Ellis et al. 1997; Gray et al. 2010; McDonald and Kristjansson 1993; Piche et al. 2004; Singh et al. 2003). These new strains are a product of recombination in several regions of the genome of two parental strains (PVYO and $\mathrm{PVY}^{\mathrm{N}}$ ); most notable are exchanges spanning the P1 and HCPro cistrons and spanning the VPg, NIa, Nib, and CP cistrons (Gray et al. 2010; Karasev and Gray 2013). The recombinant PVYN:O and PVYNWi strains now predominate in most U.S. production areas. Although the tuber-necrotic PVYNTN strain is still a relatively minor component of the overall PVY incidence, it is distributed in all U.S. seed production areas (Gray et al. 2010). Meanwhile the two parental strains of most recombinants are either rapidly decreasing in prevalence $(\mathrm{PVYO})$ or have all but disappeared $\left(\mathrm{PVY}^{\mathrm{N}}\right)$. $\mathrm{PVY}^{\mathrm{N}}$ has only been recovered from potato growing on two farms in one state since national surveys began in 2004. Multiple PVY strains are routinely found within a single seed lot or field, and strain mixtures in single plants are not uncommon (Crosslin et al. 2006; Gray et al. 2010). The reasons for the strain shifts are the subjects of ongoing studies but several factors are likely contributors, including the unintended selection for recombinant strains in seed certification programs and rogueing operations due to their milder foliar symptoms, a sizeable number of potato varieties with partial resistance genes effective against $\mathrm{PVYO}$ but not the recombinant strains (Hane and Hamm 1999; Sturz et al. 1997), and differences in relative transmission efficiency of PVY strains by different aphid vectors (Mello et al. 2011; Mondal et al. 2016a; Verbeek et al. 2010). 
PVY is transmitted to potato by more than 50 colonizing and noncolonizing aphid species in a nonpersistent, stylet-borne manner (Bradley 1954; Sigvald 1984). Aphids acquire virus during very short $(<1 \mathrm{~min})$ feeding probes in epidermal leaf cells and subsequently transmit the virus to healthy plants by shortduration probes with no latent period (Perez et al. 1996); therefore, both potato-colonizing and transient noncolonizing aphids are important vector species (Difonzo et al. 1997; Mondal et al. 2016b). Myzus persicae (Sulzer), the green peach aphid (GPA), is the most efficient aphid vector (Boquel et al. 2011; Kaliciak and Syller 2009; Mondal et al. 2016a; Verbeek et al. 2010), whereas most other species of aphids tested in controlled transmission studies are inefficient vectors (Davis et al. 2005; Halbert et al. 2003; Katis and Gibson 1985; Mello et al. 2011; Mondal et al. 2016a; Sigvald 1984). Therefore, the vast majority of studies on PVY transmission efficiency and specificity have been conducted using GPA. Although it is difficult to directly compare many of the transmission efficiency studies, most GPA clones and populations appear to be efficient vectors. In previous studies, variation in transmission efficiency could be linked more to PVY strains, isolates within a strain, or source or recipient plant species than to GPA clone (Basky and Almási 2005; Harrington and Gibson 1989; Mello et al. 2011; Mondal et al. 2016a; Shrestha et al. 2014; Sigvald 1984; Verbeek et al. 2010).

The experiments described in this study took place in New York and in Idaho and were designed to examine the effects of mixtures of PVY strains in single plants of different potato cultivars on the ability of GPA to efficiently acquire and transmit those strains to other potato plants. This will provide valuable information on whether mixed infections and potato cultivar influence PVY transmission, thereby contributing to the shift in PVY strains over the past decade.

\section{MATERIALS AND METHODS}

Aphids, virus isolates, and plant hosts. The New York GPA clone has been reared on PVY-free Physalis floridana Rydb. in a growth room maintained at 21 to $23^{\circ} \mathrm{C}$ with constant light for over 15 years. The Idaho GPA colony, initially collected from potato by Guy Bishop, Parma Research \& Extension Center, University of Idaho, was reared on Chinese cabbage (Brassica pekinensis Ruprecht) in a growth chamber maintained at 21 to $26^{\circ} \mathrm{C}, 90 \%$ relative humidity, and a photoperiod of $14 \mathrm{~h}$ of light and $10 \mathrm{~h}$ of darkness.

Several virus isolates used in the study were collected during national surveys of seed potato from 2004 to the present and included PVYO-NY09-31, PVY ${ }^{\mathrm{N}: \mathrm{O}_{-} \mathrm{NY} 09-4, \mathrm{PVYO}_{-} \mathrm{CA} 14, \mathrm{PVY}^{\mathrm{N}} \text { :O }}$ WI62, and PVYNTN-NY09-29. Isolate PVYNA-NTN-RRA1 (Lorenzen et al. 2006a) was obtained from Dr. Jonathan L. Whitworth. Additional isolates of $\mathrm{PVYO}, \mathrm{PVY}^{\mathrm{NW}}$, and a $\mathrm{PVYO} / \mathrm{NWi}$ mixture were obtained from infected 'Lamoka' potato tubers harvested from 2010 field experiments conducted in Ithaca, NY. All isolates except those obtained from the Lamoka tubers were maintained long term in lyophilized tobacco (Nicotiana tabacum L. 'Samsun-NN') leaves stored at $-20^{\circ} \mathrm{C}$. Strain types of the infecting isolates was determined using a multiplex reverse-transcription polymerase chain reaction (RT-PCR) assay developed by Lorenzen et al. (2006b) or by a novel multiplex RT-PCR (see below).

Virus source plants for the experiments conducted in New York were derived from either PVY-infected Lamoka tubers, described above, or PVY-infected 'Goldrush' or 'Red Maria' plants that were initially infected by mechanical inoculation. Virus source plants were subsequently propagated through cuttings treated with rooting hormone (Bontone; 0.1\% indole-3-butyric acid). Plants were grown in Cornell Mix (Boodley and Sheldrake, 1982) potting soil in plastic pots ( 10 by 10 by $15 \mathrm{~cm}$ ) and maintained in a greenhouse screened to exclude aphids.

Virus source plants for the Idaho experiments were virus-free tissue-culture plantlets of 'Russet Burbank' potato. The plantlets were potted in plastic pots ( 10 by 10 by $15 \mathrm{~cm}$ ) in a $2: 2: 1 \mathrm{sand} /$ peat/ vermiculite mix with encapsulated fertilizer of N-P-K at 14:14:14 (Osmocote; Scotts Miracle Gro, Marysville, OH). Plants were infected by mechanical inoculation and maintained in a greenhouse at 19 to $27^{\circ} \mathrm{C}, 70 \%$ relative humidity, and a photoperiod of $16 \mathrm{~h}$ or light and $8 \mathrm{~h}$ of darkness.

Virus source plants were mechanically inoculated with one, two, or three PVY strains. Briefly, PVY-infected leaf tissue was ground in $0.1 \mathrm{M}$ phosphate buffer (1:5), $\mathrm{pH}$ 7.4. Carborundum was applied to leaves of 3-week-old potato plants and sap was rubbed on the adaxial surface of all fully opened leaves of each plant. To obtain double- and triple-strain mixtures in source plants, sap extracted from plants infected with single strains was mixed in equal ratios and used as inoculum. All virus source plants were tested with multiplex RT-PCR to check for the presence of the desired strains. Young, fully expanded, systemically infected leaves were detached from the plant and used as the virus source for the aphid transmission experiments.

Recipient plants for the experiments conducted in New York were Red Maria seedlings generated from true seed. This provided a high-throughput method to generate many seedlings of the same size for transmission experiments. We had previously tested a large population of these seedlings $(n=340)$ to ensure that there was no variation in their susceptibility to PVY (Mello et al. 2011). True potato seed were treated with gibberellic acid-3 $(750 \mathrm{ppm})$ for 5 days and seeded in Cornell Mix potting soil in 98-cell plug trays. Seedlings were transplanted at the three-leaf stage individually into pots $(10$ by 10 by $15 \mathrm{~cm}$ ) and used as recipient plants for aphid inoculation at the four- to six-leaf stage. Recipient plants for the Idaho experiments were virus-free tissue-culture plantlets of Russet Burbank, grown as described above. Recipient plants were at the four- to six-leaf stage.

Transmission assays. Experiments in New York comparing the transmission of two PVY strains and the mixture of both viruses were done using PVYO and PVYNWi sourced from field-infected Lamoka plants and using PVYO and PVYNTN (isolates NY09-31 and NY09-29, respectively) sourced from mechanically inoculated Goldrush or Red Maria plants. Additional experiments, one in Idaho using Russet Burbank as source and another in New York using Goldrush as source, tested the transmission efficiency by GPA of single, double, and triple infections of PVYO, PVYN:O, and either PVYNA-NTN or PVYNTN. The PVYO, PVYNWi, and mixture experiment using Lamoka source tissue was repeated eight times with 20 to 40 recipient plants in each of the three treatments. All other experiments were repeated five times using 8 to 24 recipient plants for each treatment. Detached leaves from noninoculated plants were used as controls in each experiment.

Adult apterous GPA, previously starved for 1 to $2 \mathrm{~h}$ in covered plastic dishes, were allowed a 2- to 5-min acquisition access period (AAP) on a young, fully expanded source leaf systemically infected with the appropriate virus strain or combination of virus strains. Single aphids were transferred to and caged on healthy recipient potato plants for a 24 - to 48 -h inoculation access period. Plants were subsequently fogged with an insecticide mixture of pymetrozine (Endeavor 50WG) at $1.6 \mathrm{~g}\left(93 \mathrm{~m}^{2}\right)^{-1}$ and bifenthrin (Talstar P) at $15 \mathrm{ml}\left(93 \mathrm{~m}^{2}\right)^{-1}$ to kill all aphids, moved to a greenhouse, and observed for symptom development for 2 to 3 weeks. At 3 to 5 weeks postinoculation, plants were tested for PVY infection using triple-antibody sandwich enzyme-linked immunosorbent assay (TAS-ELISA) (Ellis et al. 1996). Infected plants were subsequently tested by immunocapture multiplex RT-PCR to determine the infecting strains.

Detection and differentiation of PVY strains and strain mixtures. All PVY strains used in these experiments were initially detected and differentiated using TAS-ELISA (Ellis et al. 1996) using the following monoclonal antibodies (Agdia Inc., Elkhart, IN): 4C3 detects all PVY strains, MAb2 is specific for the PVYO and $\mathrm{PVY} \mathrm{Y}^{\mathrm{O} / \mathrm{NW}}$ isolates, and 1F5 is specific for the PVYNTN isolates. 
Subsequently, strain and strain mixtures were identified by multiplex RT-PCR (Lorenzen et al. 2006a). Although this multiplex RT-PCR can distinguish mixtures of most of the strains, it cannot differentiate a mixture of PVYO, PVYN:O, and PVYNTN from a mixture of PVYO and PVYNTN (Fig. 1A, lanes 7 and 11). This was the reason for using PVYNA-NTN rather than PVYNTN in initial experiments, until a new assay was developed that could resolve a triple mixture of PVYO, PVYN:O, and PVYNTN (Fig. 1B).

To differentiate triple-strain mixtures from mixtures of $\mathrm{PVYO}$ and PVYNTN, a novel immunocapture RT-PCR was developed using three PVY strain-specific primer pairs. Immunocapture was conducted by coating wells of a 96-well PCR plate (Laboratory Products Sales, Inc., Buffalo, NY) with $100 \mu$ l of anti-PVY immunoglobulin $\mathrm{G}(0.1 \mu \mathrm{g} / \mathrm{ml})$ in $20 \mathrm{mM}$ sodium carbonate coating buffer (pH 9.6) and incubating at $37^{\circ} \mathrm{C}$ for $2 \mathrm{~h}$. The plate was then washed three times with phosphate-buffered saline containing $0.1 \%$ Tween 20 (PBST). Leaf samples homogenized in PBS containing 2\% polyvinylpyrrolidone at $1: 10(\mathrm{wt} / \mathrm{vol})$ were added to each well and incubated at $4^{\circ} \mathrm{C}$ overnight. The plate was washed with PBST four times, rinsed with deionized water, and air dried. To release viral RNA, $7.5 \mu \mathrm{l}$ of $1 \%$ Triton X100 was added to each well and the plate heated to $65^{\circ} \mathrm{C}$ for $5 \mathrm{~min}$, then placed on ice for $5 \mathrm{~min}$. An RT master mix was prepared using ImProm-II Reverse Transcription System (Promega Corp., Madison, WI), with some minor modifications (3.3 mM MgCl $2,0.5 \mathrm{mM}$ each dNTP, and $0.375 \mu \mathrm{g}$ of random hexamer primer) and $7.5 \mu \mathrm{l}$ was added to each sample well. The plate was incubated at $45^{\circ} \mathrm{C}$ for $30 \mathrm{~min}$, followed by $1 \mathrm{~h}$ at $42^{\circ} \mathrm{C}$, and then increased to $65^{\circ} \mathrm{C}$ for $15 \mathrm{~min}$ for inactivation of the transcriptase. PCR was carried out using GoTaq Green Master Mix (Promega Corp.) following the manufacturer's instructions with six strain-specific primers $(0.8 \mu \mathrm{M}$ each). The primer pairs $\mathrm{O} 1962 \mathrm{~F}$ (5'-TCAACATTCTATCCACCAAC-3')/O2296R (5'-ACGTTT GAGTGTCATGGT-3') and N:O1008F (5'-GCACGTTCCAAG GTTACC-3')/N:O1703R (5'-TCGCTTAGCATGATATTCCCT-3')
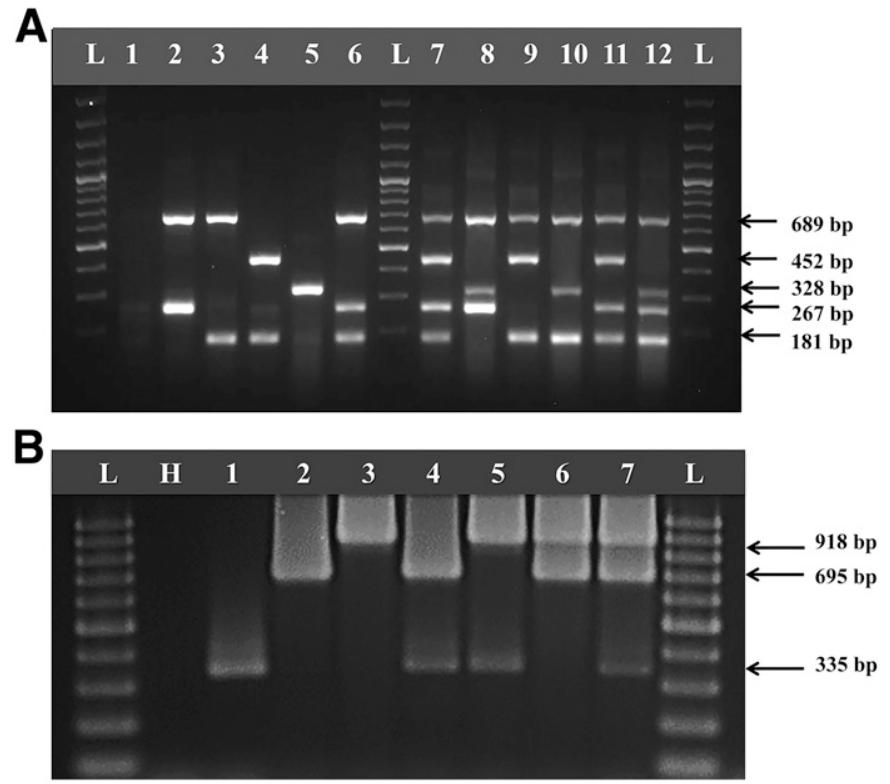

Fig. 1. A, Detection of Potato virus $Y$ (PVY) strains $\mathrm{PVYO}$, PVYN:O, and PVYNA-NTN and their mixtures by reverse-transcription polymerase chain reaction (RT-PCR) (Lorenzen et al. 2006b). Lane 1, healthy Russet Burbank; lane 2, O strain; lane 3, N:O strain; lane 4, NTN strain; lane 5, NA-NTN strain; lane 6, O+N:O; lane 7, O+NTN; lane 8, O+NA-NTN; lane 9, N:O+NTN; lane 10, N:O+NA-NTN; lane 11, O+N:O+NTN; lane 12, O+N:O+NA-NTN; and L lanes, GeneRuler 100-bp DNA Ladder (Thermo Fisher Scientific). B, Detection of PVYO ${ }^{\mathrm{PVY}} \mathrm{N}^{\mathrm{N}: \mathrm{O}}$ and PVYNTN by multiplex immunocapture RT-PCR in ethidium-bromide-stained agarose gel (2\%). Lane $\mathrm{H}$, healthy Goldrush; lane 1, O (CA14 isolate); lane 2, N:O (WI62 isolate); lane 3, NTN; lane 4, O+N:O; lane 5, N:O+NTN; lane 6, O+NTN; lane 7, O+N:O+NTN; and L lanes, GeneRuler 100-bp DNA Ladder (Thermo Fisher Scientific). were designed to amplify 335- and 695-bp fragments from the HC-Pro cistron for PVYO and PVYN:O, respectively. PVYNTN was identified by primer pair NTN7350F (5'-ACATCACCGATGAG CAGG-3') and NTN8266R (5'-GTACATACCCTCGATTAGCA-3') producing a 918-bp amplicon from the NIb cistron (Fig. 1B). cDNA $(3 \mu \mathrm{l})$ was added to the PCR mixture and adjusted to a final volume of $20 \mu \mathrm{l}$ using nuclease-free water. PCR was carried out in an ABI 2720 Thermal Cycler (Applied Biosystems, Foster City, CA) with thermal cycles of $94^{\circ} \mathrm{C}$ for $3 \mathrm{~min} ; 35$ cycles of $94^{\circ} \mathrm{C}$ for $30 \mathrm{~s}, 62^{\circ} \mathrm{C}$ for $30 \mathrm{~s}$, and $72^{\circ} \mathrm{C}$ for $1 \mathrm{~min}$; final extension at $72^{\circ} \mathrm{C}$ for $7 \mathrm{~min}$; and final hold at $4^{\circ} \mathrm{C}$. PCR products were analyzed by electrophoresis in $1.5 \%$ agarose gel stained with GelRed Nucleic Acid Gel Stain (Biotium Inc., Hayward, CA) or ethidium bromide and visualized on a UV transilluminator.

Statistical analysis. Statistical analyses of experiments using source plants derived from infected Lamoka tubers were conducted using effect likelihood ratios and odds ratios determined by fitting data to a nominal logistic model, contingency analysis, distribution probability analysis, and $\chi^{2}$ tests. Analyses were done with JMP Pro (version 10.0.2; SAS Institute Inc., Cary, NC).

A generalized linear model was fitted to compare means among the treatments for both the varietal comparison of the overall infection percentage using Goldrush and Red Maria source plants for the PVYO and PVYNTN single- and double-strain treatments, as
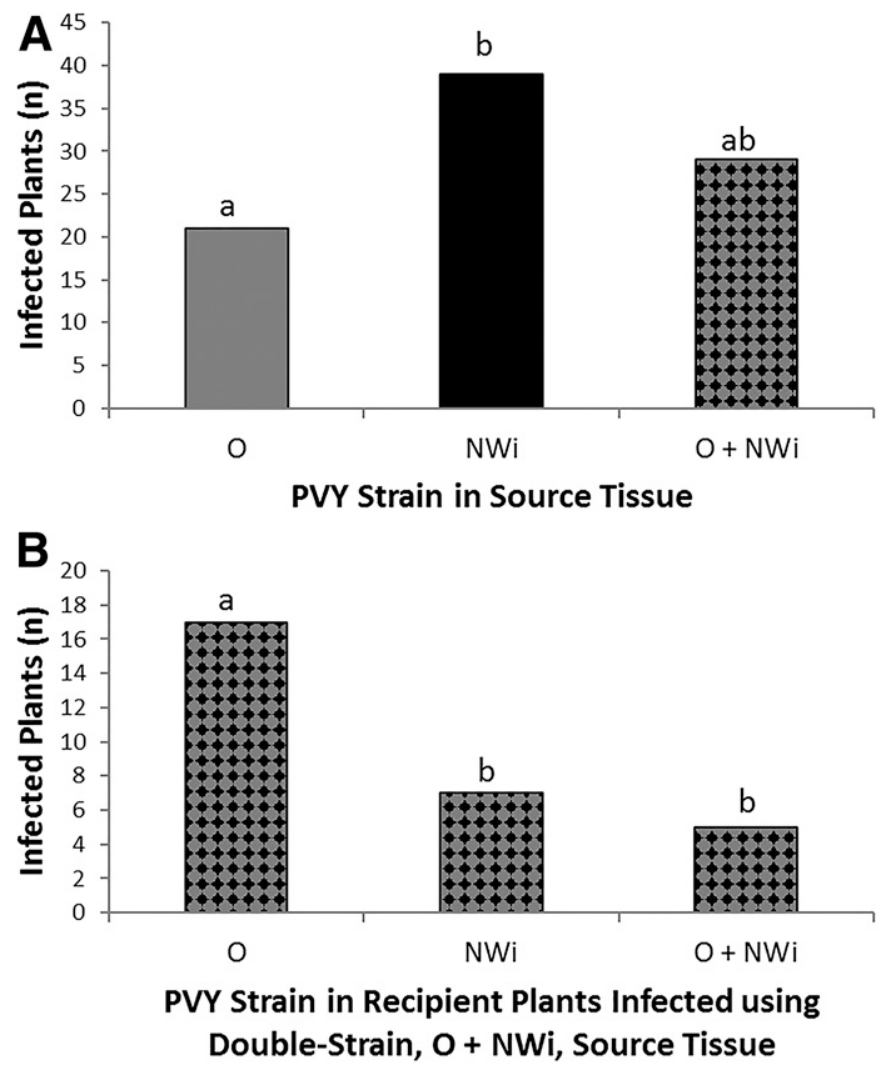

Fig. 2. A, Number of recipient Red Maria plants infected by single Myzus persicae (green peach aphid) adults given an acquisition access period on Lamoka potato plants infected with Potato virus $Y$ (PVY) strains PVYO, $\mathrm{PVY}^{\mathrm{NWi}}$, or a mixture of both strains. Numbers of infected plants were calculated from eight experiments using a total of 252 recipient plants per source tissue. Letters above the bars indicate significant difference in odds ratios $(P=$ 0.0118 ) determined with a nominal logistic model. B, Identification of the PVY strains infecting the 29 plants (A, mixture) inoculated by aphids fed on the source tissue infected with both PVYO and PVYNWi. Virus strain was determined by immunocapture multiplex reverse-transcription polymerase chain reaction (Lorenzen et al. 2006b). Letters above the bars indicate significant difference in distribution probability analysis $\left(\chi^{2}=8.08, P=0.0176\right.$, df $=2$ ). 
well as the experiment where mixed-strain treatments (single, double, and triple) were compared separately for Russet Burbank and Goldrush source cultivars. Differences and interactions within the treatments were evaluated using logistic regression by PROC GENMOD with a logit-link transformation in SAS version 9.4 (SAS Institute). For the varietal comparison, pairwise contrasts were used to compare the infection status of the strain treatments of the two varieties. In addition, maximum-likelihood of percent infection from the two-way strain mixtures in the experiment with Goldrush and Red Maria cultivars was estimated in a proportional odds model with random effects, assuming a multinomial distribution using PROC-GLIMMIX with generalized logit link transformation in SAS version 9.4. For the mixed-strain treatments, differences in the numbers of single-strain, doublestrain, and triple-strain infections in plants inoculated from a double-strain source and triple-strain source were compared by $\chi^{2}$ pairwise contrasts. There were significant interactions in regard to percent infection by specific strains or strain combinations among mixtures; therefore, data were sorted by mixture and analyzed separately within each mixture. Within the double mixtures, there were significant interactions between combinations; therefore, data were analyzed within each combination separately.

\section{RESULTS}

PVYO-PVYNWi mixture experiments. The transmission efficiency of PVYNWi (15.5\%) was significantly higher than PVYO (8.3\%) when aphids were allowed an AAP on Lamoka source plants infected with the single strains (odds ratio $P=0.0118$ for $\mathrm{PVYO}$ and PVYNWi source strains). Transmission efficiency from source plants infected with a mixture of both strains was intermediate $(11.5 \%)$ but not significantly different from either single source alone (Fig. 2A). When the 29 recipient plants infected with PVY by the aphids given an AAP on the mixed-infection source plant were analyzed, PVYO infected significantly more plants $(58.6 \%)$ than either PVYNWi alone (24.1\%) or both strains together $(17.2 \%)$ (Fig. 2B).

PVYO-PVYNTN mixture experiments. Although neither cultivar effect nor strain effect alone was significant (cultivar: $P=$ 0.432, $\chi^{2}=0.62$, df $=1$; strain: $P=0.107, \chi^{2}=4.46$, df $\left.=2\right)$, the cultivar-strain interaction $\left(P=0.025, \chi^{2}=7.37, \mathrm{df}=2\right)$ had a significant effect on transmission efficiency (Fig. 3). The transmission efficiency of PVYO was less than PVYNTN when aphids were given an AAP on either Goldrush or Red Maria plants infected with either strain alone, although the differences were not significant. Transmission efficiency from plants infected with both strains was lower from Red Maria (22\%) than from Goldrush (48\%) (Fig. 3) and the composition of strains transmitted differed between the cultivars. Single aphids allowed an AAP on Goldrush infected with both $\mathrm{PVYO}^{\mathrm{O}}$ and PVYNTN transmitted each of the strains and the mixture in nearly equal proportions (Fig. 3A, inset). In contrast, aphids allowed an AAP on Red Maria infected with both PVYO and PVYNTN transmitted PVYO more than twice as often than either PVYNTN alone or both strains together (Inset Figure 3B).

Three-strain mixture experiments. Overall transmission efficiency, as measured by percentage of recipient plants infected, regardless of strain transmitted, varied significantly among the virus strain treatments using both Russet Burbank and Goldrush as virus source plants (Fig. 4). Although transmission efficiency was highest from plants infected with three virus strains for both cultivars, transmission efficiency from plants infected with one or two strains of PVY was variable, indicating that mixed infections are not always better sources of virus that could contribute more toward secondary virus spread than singly infected plants.

In all instances where PVYO was present in the mixed-infected source tissue (PVYO and PVYN:O, PVYO and PVYNTN/NA-NTN, or all three strains), it was found to infect the highest number of recipient plants regardless of the source cultivar (Fig. 5). However, the difference was only significant for the PVYO and PVYNA-NTN mixture and the three-way mixture acquired from Russet Burbank source tissue. This is similar to the significant difference observed

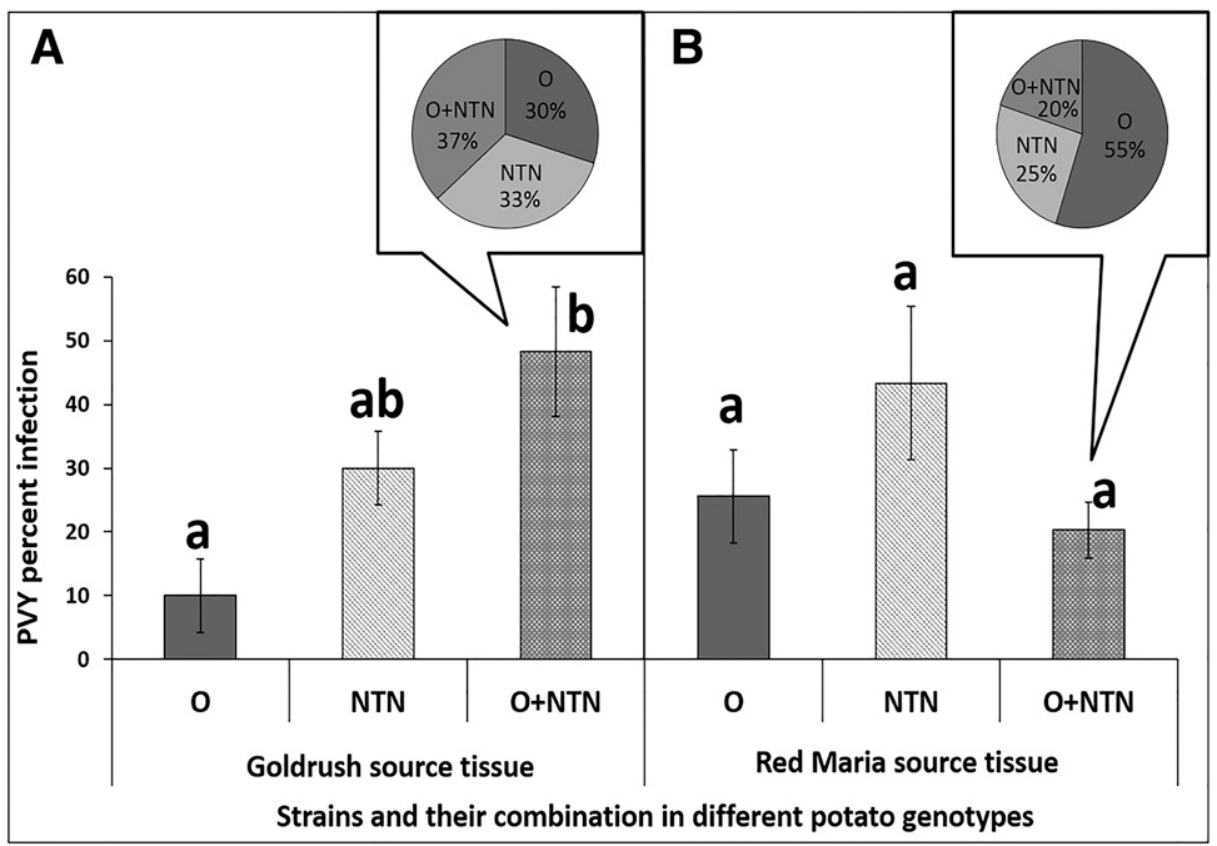

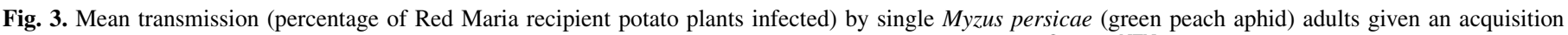

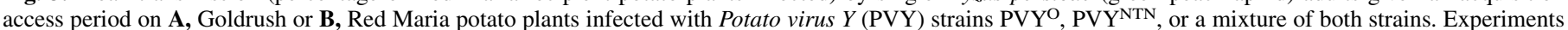

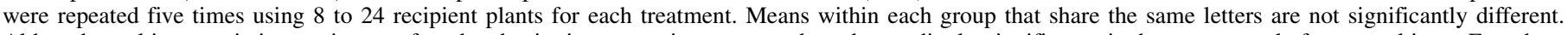

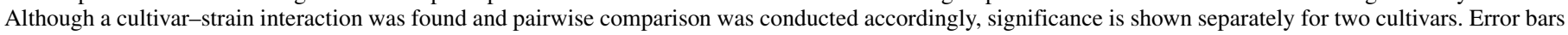

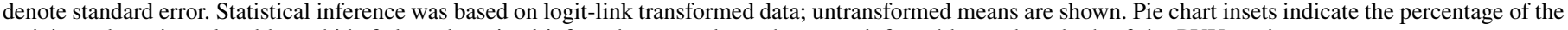
recipient plants inoculated by aphids fed on the mixed-infected source plants that were infected by each or both of the PVY strains. 
with Lamoka PVYO and PVYNWi mix-infected source tissue (Fig. 2B) and the nonsignificant trend observed with Red Maria PVYO and PVYNTN mix-infected source tissue (Fig. 3B, inset). In the absence of PVYO, both strains PVYN:O and PVYNTN alone and together were transmitted at similar efficiencies from Russet Burbank source plants, whereas PVYNTN was transmitted at significantly higher efficiencies from the Goldrush source plants (Fig. 5). All single strains and all two-strain mixtures were transmitted from Goldrush source plants infected with all three strains. The relative transmission efficiencies of single and twostrain mixtures were different from Russet Burbank source plants infected with all three strains; the mixture of PVYN:O and PVYNA-NTN was not transmitted. No single aphid transmitted all three strains from triple-infected source plants of either cultivar (Fig. 5).

\section{DISCUSSION}

The ordinary strain of PVY $(\mathrm{PVYO})$ is declining as an important virus strain affecting seed potato production in the United States, while the recombinant strains, especially PVYNWi, are becoming more prevalent (Gray et al. 2010; Karasev and Gray 2013). Whether differential aphid transmission efficiency of PVY strains is contributing to this strain shift has been the subject of many studies. Several studies have investigated the transmission efficiency of PVY strains and strain mixtures (Basky and Almási 2005; Harrington and Gibson 1989; Mello et al. 2011; Mondal et al. 2016a; Srinivasan et al. 2012; Sigvald 1984; Syller and Grupa 2014; Verbeek et al. 2010) and results have been generally inconclusive that recombinant strains are transmitted more efficiently. One consistency among all the studies is the use of $M$. persicae (GPA) as the vector, simply because it is the most efficient. Most other aphid species transmit at relatively low efficiencies, which does not allow accurate measurements, especially if single aphids need to be transferred to recipient plants to tease apart the differential transmission from mixed infections under controlled conditions. There are some differences among GPA clones with respect to PVY transmission efficiency (Verbeek et al. 2010) but all are still efficient vectors. The inconsistencies in results of this and previous studies on differential transmission of PVY strains by GPA under laboratory conditions are more likely attributed to virus isolates, host plants (both source and recipient), and host cultivars. Our studies focused on potato-to-potato transmission and used multiple isolates within strains as well as multiple potato cultivars in an attempt to better understand the most influential factors in PVY strain transmission efficiencies from single and mixed infections.

Our experiment with $\mathrm{PVYO}$ and PVYNWi provided some evidence that PVYNWi was transmitted more efficiently than PVYO from single infections; however, PVYO was found to be preferentially transmitted from mixed infections of the two strains. Further experiments failed to support more efficient transmission of recombinant strains over the ordinary strain using other PVYO and $\mathrm{PVYN}: \mathrm{O}$ isolates and potato cultivars as virus source. Whether these results are a function of virus isolate, potato cultivar, or both is unknown. Two previous studies (Srinivasan et al. 2012; Syller and Grupa 2014) found that recombinant strains were preferentially transmitted over ordinary strains from a mixture but these contrast with reports that $\mathrm{PVY} \mathrm{Y}^{\mathrm{N}: \mathrm{O} / \mathrm{NWi}}$ does not have a competitive transmission advantage over PVYO (Mello et al. 2011; Mondal et al. 2016a; Verbeek et al. 2010).

The competitive advantage in transmission efficiency of PVYNTN over PVYO has been reported by several studies (Basky and Almási 2005; Carroll et al. 2016; Mondal et al. 2016a; Srinivasan et al. 2012, Syller and Grupa 2014). Although the results were not statistically significant, our data also indicate that PVYNTN isolates were transmitted with greater or equal efficiency than $\mathrm{PVYO}^{\mathrm{O}}$ when acquired from the various potato cultivars infected with one virus strain (Figs. 3 and 4). PVYNTN is increasing in incidence and geographic distribution within the U.S. seed potato crop but it has remained a relatively minor component of overall PVY incidence. Similar to results for PVYO + PVYNWi mixed infections, transmission from PVYO + PVYNTN mixed infections favored PVYO transmission (Figs. 3B and 5). These results are in contrast to those reported by Syller and Grupa (2014), where transmission from PVYO and PVYNTN mixed infections favored PVYNTN. Although no general conclusions can be drawn from the multitude of transmission studies on PVY strains, it is apparent that transmission

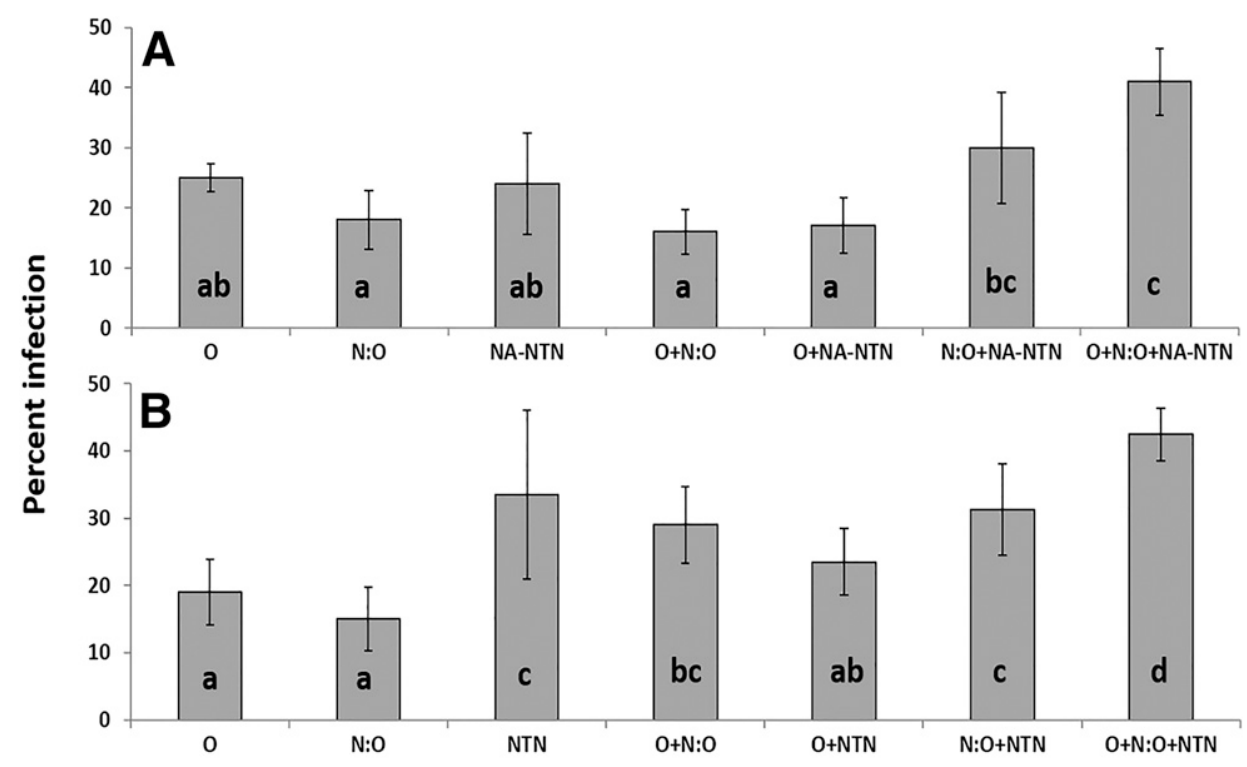

Strain or strain combinations used as virus source tissue for aphid inoculation

Fig. 4. Mean transmission (percentage of Red Maria recipient potato plants testing positive for Potato virus $Y$ [PVY]) by single Myzus persicae (green peach aphid) adults given an acquisition access period on A, Russet Burbank or B, Goldrush potato plants infected with PVYO, PVYN:O, PVYNTN/NA-NTN, or all possible mixtures of the strains. Experiments were repeated five times using 8 to 24 recipient plants for each treatment. Means within each panel that share the same letters are not significantly different. Error bars denote standard error of mean. Statistical inference was based on logit-link transformed data; untransformed means are shown. 
efficiency as measured by the number of plants that become infected following inoculation by viruliferous aphids is far too simplistic an approach to tease out factors that may have profound effects on PVY strain-specific dispersal within and between potato fields.

Virus acquisition by aphids and subsequent transmission efficiency may be affected by vector and host specificity, viral fitness, distribution and concentration of strains and isolates within the plant host, and synergistic and antagonistic interactions among coinfecting viruses, strains, and isolates (Carroll et al. 2016; Cervantes and Alvarez 2011; Domingo 2010; Mondal 2014; Mondal et al. 2016a; Robert and Bourdin 2001; Syller and Grupa 2014; Verbeek et al. 2010; Wargo and Kurath 2012). Host specificity is affected by various factors, including the age of the plant at infection, distribution of virus particles within the plant, the physiological responses to virus infection, and plant resistance genes (Chikh-Ali et al. 2014; Cockerham 1970; Jones 1990). A faster-replicating virus in a coinfection often has a competitive advantage (Zwart et al. 2009). The difference in virus titer and distribution of specific strains and isolates within potato cultivars might partially explain the altered transmission efficiency of the same isolates of PVYO and PVYNTN from Goldrush, Red Maria, and Russet Burbank. Differences in systemic virus movement and distribution were reported by Basky and Almási (2005), in which PVYN $^{\mathrm{N}}$ was found to increase more rapidly and infect more segments and progeny tubers than PVYO. A similar phenomenon of higher virus titer was also found in PVYNTN-infected hairy nightshade and Russet Burbank compared with PVYO and PVYN:O (Cervantes and Alvarez 2011) as well as in PVYO and PVYNTN mix-infected potato plants derived from true seed of Red Maria (Carroll et al. 2016).

Additionally, host responses to viral infection and plant-resistant genes should be taken into consideration for their effects on transmission efficiencies. PVYO infection in Goldrush was often accompanied by a systemic vein necrosis and necrotic areas in the systemically infected leaves. This is indicative that Goldrush is carrying one or more of the poorly characterized $N y$ resistance genes (Cockerham 1970) that tend to be strain specific, most notably against $\mathrm{PVYO}$, and convey a type of resistance manifested as a systemic hypersensitive response restricting local virus movement but allowing systemic movement. Extreme hypersensitive reactions related to $N y$ genes are apparent in some cultivars (e.g., 'Pike') that ultimately result in plant death but also limit virus acquisition by aphids while the plant is growing (Carroll et al. 2016). Interestingly, no visible hypersensitive reactions were observed in Goldrush plants infected with mixtures of PVYO with

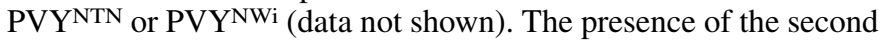

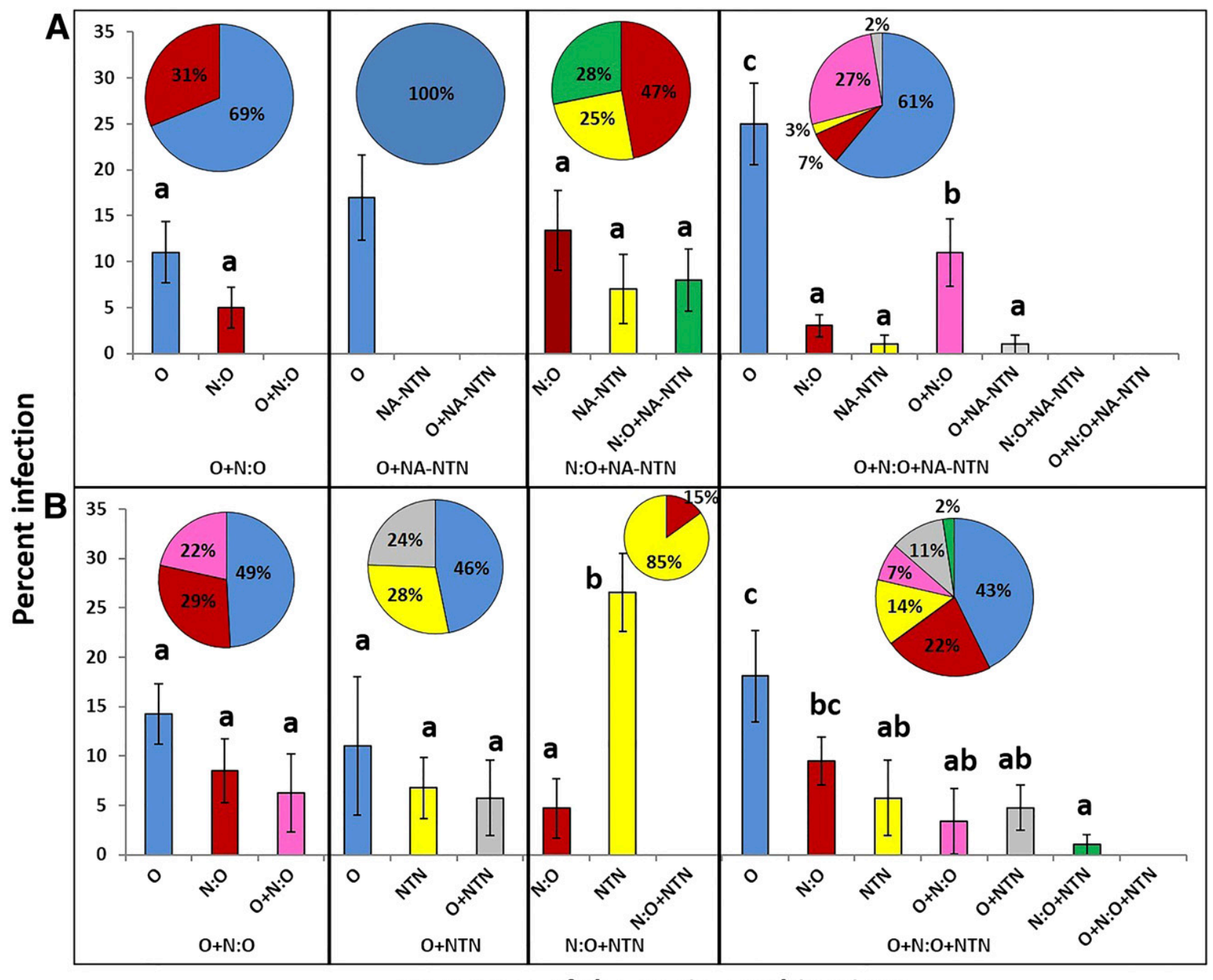

\section{Outcomes of the strain combinations}

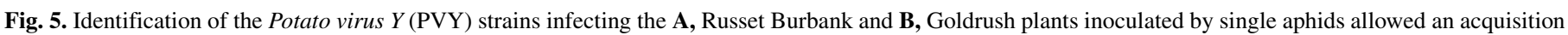

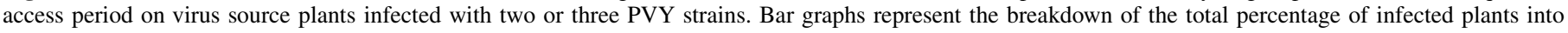

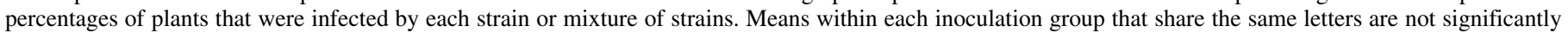

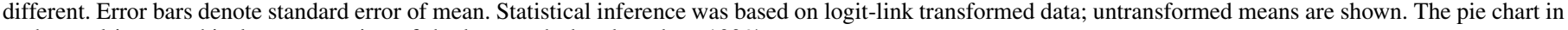
each panel is a graphical representation of the bar graph data based on $100 \%$. 
strain may suppress the $\mathrm{PVYO}^{-}$-specific host defense response or may facilitate the local movement of both viruses. These may explain the increased transmission efficiency of PVYO from Goldrush plants infected with strain mixtures compared with plants infected with PVYO alone. There is no evidence that Red Maria or Russet Burbank are carrying any of the $N y$ genes. More studies will be needed to better understand how various strains interact with different cultivars and how these interactions may change with the introduction of mixtures of strains in the same plant. Virus movement and distribution in different cultivars will affect not only the importance of these plants as sources of virus for aphids but also the vertical transmission of viruses to progeny tubers.

Differences in PVY strain transmission from single and mixed infections measured as percentage of recipient plants inoculated also does not take into account the potential virus interactions with the aphid. Clearly, from our results and previous studies, a single aphid is capable of concomitant transmission of two strains of PVY, albeit at a lower frequency than transmission of any one PVY strain. Transmission efficiency is influenced by the accessibility of virus to the feeding aphid (i.e., both viruses must be present in the same epidermal cells or in closely associated cells). Although we determined that different virus strains were present in the source tissue on which the aphids were feeding, we have no information on the relative distribution or titers of the different strains in the mixed infections. Facilitative and antagonistic interactions between plant viruses in mixed infections are possible (DaPalma et al. 2010; Dietrich and Maiss 2003; García-Cano et al. 2006; Rochow and Ross 1955; Syller 2012; Takeshita et al. 2004; Vance 1991). Syller and Grupa (2014) reported antagonism between PVYO and PVYN and also PVYO and PVYNTN that resulted in a significant reduction in $\mathrm{PVYO}$ titer. Similar observations were reported by Cervantes and Alvarez (2011) and, in that study, the transmission efficiency of PVYO from the mixed-infected plants in both studies was much lower than PVYNTN. Data from our unpublished work indicates that relative virus titers of two strains will vary considerably depending on time after infection and the potato cultivar, as well as the strains and isolates within a strain.

Transmission efficiency also is a function of the virus binding to and releasing from virus receptors on the aphid stylets (Blanc et al. 2011; Uzest et al. 2007, 2010). Compounding the stylet binding is a question of whether the helper component (HCPro), the virus encoded protein that acts as a bridge to bind virus to the stylet, is strain or isolate specific or generic in its ability to bind multiple strains. The order of HCPro-virus acquisition may also affect which strains and their relative proportions are able to bind to the stylets. We have no direct information on which strains may have been bound to or released from the aphid stylets. However, our data suggest that virus availability to the probing aphid in the plant, and not the virus-aphid interaction, is the more important criterion in determining which strain or strains are transmitted. The data in Figure 5 indicate that every two-way combination of virus strains, with the exception of PVYO + PVYNA-NTN, was able to be acquired and released by individual aphids, but not every combination was easily accessible to feeding aphids. For example, PVYO + PVYN:O was not transmitted from the double infection in Russet Burbank but, when PVYNA-NTN was added to the mix, PVYO + PVYN:O were efficiently transmitted together. Similarly, PVYN:O + PVYNTN was not transmitted from the double infection in Goldrush but they were transmitted together from the triple infection. How the addition of the third strain in the infection alters the titer or distribution of the other virus strains to make them more accessible to the aphid is unknown. Less likely, but a possibility, is that the third virus provides a factor that enhances binding or release dynamics in the stylet.

Clearly, the dynamics of PVY strain transmission are complex and influenced by many factors and interactions, and there is much work to be done to better understand all the mechanisms at work. Results from the present study do not support the hypothesis that differential aphid transmission of PVY strains contribute significantly to the observed recent shift toward recombinant strains in the field; however, controlled laboratory studies cannot mimic all conditions or variables present in the field. The differential transmission of PVY strains observed under field conditions may be different than what has been observed under controlled conditions, especially if other aphid species are the primary vectors. Although difficult, these experiments would best be conducted in the field, where movement of known sources of virus can be attributed to flights of known aphid species moving through the crop. A recent report indicates that spread of PVYNTN is more likely than that of PVYO, given the experimental conditions in the United Kingdom (Lacomme et al. 2016), and has likely contributed to the increased prevalence of PVYNTN in recent years.

\section{ACKNOWLEDGMENTS}

We thank A. Karasev and H. R. Pappu for providing valuable suggestions for this study; W. Price and E. Mudrak for advice on statistical analysis; and D. Shrestha, J. Ingram, D. Smith, D. Hall, and A. Workman for their excellent technical assistance. Funding for this study was provided by USDA Specialty Crops Research Initiative (2009-51181-05894 and 2014-51181-22373), the UK Biotechnology and Biological Sciences Research Council grant number BB/L011840/1 as part of the joint USDA-NSF-NIH-BBSRC Ecology and Evolution of Infectious Diseases program, and the Idaho Potato Commission.

\section{LITERATURE CITED}

Basky, Z., and Almási, A. 2005. Differences in aphid transmissibility and translocation between PVYN and PVYO isolates. J. Pest Sci. 78:67-75.

Blanc, S., Uzest, M., and Drucker, M. 2011. New research horizons in vectortransmission of plant viruses. Curr. Opin. Microbiol. 14:483-491.

Boodley, J. W., and Sheldrake, R. 1982. Cornell peat-lite mixes for commercial plant growing. Cornell Inf. Bull. Cornell University, Ithaca, NY.

Boquel, S., Ameline, A., and Giordanengo, P. 2011. Assessing aphids Potato virus $Y$-transmission efficiency: A new approach. J. Virol. Methods 178:63-67.

Bradley, R. H. E. 1954. Studies of the mechanism of transmission of Potato virus $Y$ by the green peach aphid, Myzus persicae (Sulz.) (Homoptera: Aphididae). Can. J. Zool. 32:64-73.

Carroll, J. E., Smith, D. M., and Gray, S. M. 2016. Preferential acquisition and inoculation of PVYNTN over PVYO in potato by the green peach aphid Myzus pericae (Sulzer). J. Gen. Virol. 97:797-802.

Cervantes, F. A., and Alvarez, J. M. 2011. Within plant distribution of Potato virus $Y$ in hairy nightshade (Solanum sarrachoides): An inoculum source affecting PVY aphid transmission. Virus Res. 159:194-200.

Chikh-Ali, M., Rowley, J. S., Kuhl, J., Gray, S. M., and Karasev, A. V. 2014. Evidence of a monogenic nature of the $\mathrm{Nz}$ gene conferring resistance against Potato virus $Y$ strain Z (PVYZ) in Potato. Am. J. Potato Res. 91:649-654.

Cockerham, G. 1970. Genetical studies on resistance to potato viruses X and Y. Heredity 25:309-348.

Crosslin, J. M., Hamm, P. B., Eastwell, K. C., Thornton, R. E., Brown, C. R., Corsini, D., Shiel, P. J., and Berger, P. H. 2002. First report of the necrotic strain of Potato virus $Y\left(\mathrm{PVY}^{\mathrm{N}}\right)$ on potatoes in the northwestern United States. Plant Dis. 86:1177.

Crosslin, J. M., Hamm, P. B., Hane, D. C., Jaeger, J., Brown, C. R., Shiel, P. J. 2006. The occurrence of PVYO $\mathrm{PVY}^{\mathrm{N}}$, and $\mathrm{PVY}^{\mathrm{N}: \mathrm{O}}$ strains of Potato virus $Y$ in certified potato seed lot trials in Washington and Oregon. Plant Dis. 90: 1102-1105.

DaPalma, T., Doonan, B. P., Trager, N. M., and Kasman, L. M. 2010. A systematic approach to virus-virus interactions. Virus Res. 149:1-9.

Davis, J., Radcliffe, E., and Ragsdale, D. W. 2005. Soybean aphid, Aphis glycines Matsumura, a new vector of Potato virus $Y$ in potato. Am. J. Potato Res. 82:197-201.

Dietrich, C., and Maiss, E. 2003. Fluorescent labelling reveals spatial separation of potyvirus populations in mixed infected Nicotiana benthamiana plants. J. Gen. Virol. 84:2871-2876.

Difonzo, C. D., Ragsdale, D. W., Radcliffe, E. B., Gudmestad, N. C., and Secor, G. A. 1997. Seasonal abundance of aphid vectors of Potato virus $Y$ in the Red River Valley of Minnesota and North Dakota. J. Econ. Entomol. 90: 824-831.

Domingo, E. 2010. Mechanisms of viral emergence. Vet. Res. 41:38.

Ellis, P., Stace Smith, R., Bowler, G., and Mackenzie, D. J. 1996. Production of monoclonal antibodies for detection and identification of strains of Potato virus Y. Can. J. Plant Pathol. 18:64-70.

Ellis, P., Stace-Smith, R., and de Villiers, G. 1997. Identification and geographic distribution of serotypes of Potato virus Y. Plant Dis. 81:481-484. 
FAO. 2008. The International Year of the Potato-IYP 2008. Online publication. Food and Agriculture Organization of the United Nation. http:// www.fao.org/agriculture/crops/thematic-sitemap/theme/hort-indust-crops/ international-year-of-the-potato/en/

Frost, K. E., Groves, R. L., and Charkowski, A. O. 2013. Integrated control of potato pathogens through seed potato certification and provision of clean seed potatoes. Plant Dis. 97:1268-1280.

García-Cano, E., Resende, R. O., Fernández-Muñoz, R., and Moriones, E. 2006. Synergistic interaction between Tomato chlorosis virus and Tomato spotted wilt virus results in breakdown of resistance in tomato. Phytopathology 96:1263-1269.

Gray, S., De Boer, S., Lorenzen, J., Karasev, A., Whitworth, J., Nolte, P. 2010. Potato virus Y: An evolving concern for potato crops in the United States and Canada. Plant Dis. 94:1384-1397.

Halbert, S. E., Corsini, D. L., and Wiebe, M. A. 2003. Potato virus $Y$ transmission efficiency for some common aphids in Idaho. Am. J. Potato Res. 80:87-91.

Hane, D. C., and Hamm, P. B. 1999. Effects of seedborne Potato virus $Y$ infection in two potato cultivars expressing mild disease symptoms. Plant Dis. 83:43-45.

Harrington, R., and Gibson, R. W. 1989. Transmission of Potato virus $Y$ by aphids trapped in potato crops in southern England. Potato Res. 32:167-174.

Jones, R. A. C. 1990. Strain group specific and virus specific hypersensitive reactions to infection with potyviruses in potato cultivars. Ann. Appl. Biol. 117:93-105.

Kaliciak, A., and Syller, J. 2009. New hosts of Potato virus $Y$ (PVY) among common wild plants in Europe. Eur. J. Plant Pathol. 124:707-713.

Karasev, A. V., and Gray, S. M. 2013. Continuous and emerging challenges of Potato virus $Y$ in potato. Annu. Rev. Phytopathol. 51:571-86.

Katis, N., and Gibson, R. W. 1985. Transmission of Potato virus $Y$ by cereal aphids. Potato Res. 28:65-70.

Kerlan, C., and Moury, B. 2008. Potato virus Y. Pages 287-296 in: Encyclopedia of Virology, Vol. 4, 3rd ed.. B. W. J. Mahy and M. H. V. van Regenmortel, eds. Elsevier, Oxford.

Lacomme, C., Davie, K., Holmes, R., and Pickup, J. 2016. Genetic diversity of PVY isolates in potato crops: Impact of strain competition and ability to overcome host resistance mechanisms. (Abstr.) 16th Triennial Meet. Virol. Sect. Eur. Assoc. Potato Res. and 8th Annu. Meet. PVYwide Organ. Ljubljana, Slovenia. https://colloque.inra.fr/ipve2016/Downloads/WEB-Abstract-book2

Lorenzen, J. H., Meacham, T., Berger, P. H., Shiel, P. J., Crosslin, J. M., Hamm, P. B. 2006a. Whole genome characterization of Potato virus $Y$ isolates collected in the western USA and their comparison to isolates from Europe and Canada. Arch. Virol. 151:1055-1074.

Lorenzen, J. H., Piche, L. M., Gudmestad, N. C., Meacham, T., and Shiel, P. 2006b. A multiplex PCR assay to characterize Potato virus $Y$ isolates and identify strain mixtures. Plant Dis. 90:935-940.

McDonald, J. G., and Kristjansson, G. T. 1993. Properties of strains of Potato virus $Y(\mathrm{~N})$ in North-America. Plant Dis. 77:87-89.

McDonald, J. G., and Singh, R. P. 1996. Response of potato cultivars to North American isolates of PVYNTN. Am. Potato J. 73:317-323.

Mello, A. F. S., Olarte, R. A., Gray, S. M., and Perry, K. L. 2011. Transmission efficiency of Potato virus $Y$ strains $\mathrm{PVY}^{\mathrm{O}}$ and $\mathrm{PVY}^{\mathrm{N}-\mathrm{Wi}^{\mathrm{i}}}$ by five aphid species. Plant Dis. 95:1279-1283.

Mondal, S. 2014. Studies on the relationships of Potato virus $Y$ and Potato leaf roll virus with their aphid vectors in potato. Ph.D. dissertation, University of Idaho, Moscow.

Mondal, S., Wenninger, E. J., Hutchinson, P. J. S., Whitworth, J. L., Shrestha, D., Eigenbrode, S. D., and Bosque-Perèz, N. A. 2016a. Comparison of transmission efficiency of various isolates of Potato virus $Y$ among three aphid vectors. Entomol. Exp. Appl. 158:258-268.

Mondal, S., Wenninger, E. J., Hutchinson, P. J. S., Wiebe, M., Eigenbrode, S. D., and Bosque-Perèz, N. A. 2016b. Contribution of non-colonizing aphids to Potato virus $Y$ prevalence in potato in Idaho. Environ. Entomol. 45:1445-1462.

Nolte, P., Whitworth, J. L., Thornton, M. K., and McIntosh, C. S. 2004. Effect of seedborne Potato virus $Y$ on performance of Russet Burbank, Russet Norkotah, and Shepody potato. Plant Dis. 88:248-252.
Perez, P., Tjallingii, W. F., and Fereres, A. 1996. Probing behavior of Myzus persicae during transmission of Potato virus $Y$ to pepper and tobacco plants. J. Plant Dis. Prot. 103:246-254.

Piche, L. M., Singh, R. P., Nie, X., and Gudmestad, N. C. 2004. Diversity among Potato virus $Y$ isolates obtained from potatoes grown in the United States. Phytopathology 94:1368-1375.

Ragsdale, D., Radcliffe, E., and DiFonzo, C. D. 2001. Epidemiology and field control of PVY and PLRV. Pages 237-270 in: Virus and Virus-like Diseases of Potatoes and Production of Seed-Potatoes. G. Lobenstein, P. H. Berger, A. A. Brunt, and R. Lawson, eds. Kluwer Academic Publishers, Dordrecht, The Netherlands.

Robert, Y., and Bourdin, D. 2001. Aphid transmission of potato viruses. Pages 195-225 in: Virus and Virus-like Diseases of Potatoes and Production of Seed-Potatoes. G. Lobenstein, P. H. Berger, A. A. Brunt, and R. Lawson, eds. Kluwer Academic Publishers, Dordrecht, The Netherlands.

Rochow, W. F., and Ross, A. F. 1955. Virus multiplication in plants doubly infected by potato viruses $\mathrm{X}$ and $\mathrm{Y}$. Virology 1:10-27.

Shrestha, D., Wenninger, E. J., Hutchinson, P. J. S., Whitworth, J. L., Mondal, S., Eigenbrode, S. D., and Bosque-Pérez, N. A. 2014. Interactions among potato genotypes, growth stages, virus strains, and inoculation methods in the Potato virus $Y$ and green peach aphid pathosystem. Environ. Entomol. 43:662-671.

Sigvald, R. 1984. The relative efficiency of some aphid species as vectors of Potato virus $Y$ O $\left(\mathrm{PVY}^{\mathrm{O}}\right)$. Potato Res. 27:285-290.

Singh, R. P. 1992. Incidence of the tobacco veinal necrotic strain of Potato virus $Y\left(\mathrm{PVY}^{\mathrm{N}}\right)$ in Canada in 1990 and 1991 and scientific basis for eradication of the disease. Can. Plant Dis. Surv. 72:113-119.

Singh, R. P., McLaren, D. L., Nie, X., and Singh, M. 2003. Possible escape of a recombinant isolate of Potato virus $Y$ by serological indexing and methods of its detection. Plant Dis. 87:679-685.

Srinivasan, R., Hall, D. G., Cervantes, F. A., Alvarez, J. M., and Whitworth, J. L. 2012. Strain specificity and simultaneous transmission of closely related strains of a potyvirus by Myzus persicae. J. Econ. Entomol. 105:783-791.

Sturz, A. V., Diamond, J. F., and Stewart, J. G. 1997. Evaluation of mosaic symptom expression as an indirect measure of the incidence of $\mathrm{PVYO}$ in potato cv. Shepody. Can. J. Plant Pathol. 19:145-148.

Syller, J. 2012. Facilitative and antagonistic interactions between plant viruses in mixed infections. Mol. Plant Pathol. 13:204-216.

Syller, J., and Grupa, A. 2014. The effects of co-infection by different Potato virus $Y(\mathrm{PVY})$ isolates on virus concentration in solanaceous hosts and efficiency of transmission. Plant Pathol. 63:466-475.

Takeshita, M., Shigemune, N., Kikuhara, K., Furuya, N., and Takanami, Y. 2004. Spatial analysis for exclusive interactions between subgroups I and II of Cucumber mosaic virus in cowpea. Virology 328:45-51.

Uzest, M., Gargani, D., Dombrovsky, A., Cazevieille, C., Cot, D., and Blanc, S. 2010. The "acrostyle": A newly described anatomical structure in aphid stylets. Arthropod Struct. Dev. 39:221-229.

Uzest, M., Gargani, D., Drucker, M., Hébrard, E., Garzo, E., Candresse, T. 2007. A protein key to plant virus transmission at the tip of the insect vector stylet. Proc. Natl. Acad. Sci. USA 104:17959-17964.

Vance, V. B. 1991. Replication of Potato virus X RNA is altered in coinfections with potato virus Y. Virology 182:486-494.

van den Heuvel, J. F. J. M., van der Vlugt, R. A. A., Verbeek, M., de Haan, P. T., and Huttinga, H. 1994. Characteristics of a resistance-breaking isolate of Potato virus $Y$ causing potato tuber necrotic ringspot disease. Eur. J. Plant Pathol. 100:347-356.

Verbeek, M., Piron, P. G. M., Dullemans, A. M., Cuperus, C., and van der Vlugt, R. A. A. 2010. Determination of aphid transmission efficiencies for N, NTN and Wilga strains of Potato virus Y. Ann. Appl. Biol. 156:39-49.

Wargo, A. R., and Kurath, G. 2012. Viral fitness: Definitions, measurement, and current insights. Curr. Opin. Virol. 2:538-545.

Whitworth, J. L., Nolte, P., McIntosh, C., and Davidson, R. 2006. Effect of Potato virus $Y$ on yield of three potato cultivars grown under different nitrogen levels. Plant Dis. 90:73-76.

Zwart, M. P., van der Werf, W., van Oers, M. M., Hemerik, L., van Lent, J. M. V., de Visser, J. A. G. M. 2009. Mixed infections and the competitive fitness of faster-acting genetically modified viruses. Evol. Appl. 2:209-221. 